\title{
UPAYA PEMBERDAYAAN MASYARAKAT MELALUI DETEKSI DINI DAN PENGENDALIAN PENYAKIT DEGENERATIF PADA LANSIA DI DSN.KARANG PUCANG, DS.NGANCAR, KEC.PITU WILAYAH KERJA PUSKESMAS PITU KABUPATEN NGAWI
}

\author{
Community Empowerment Efforts Through Early Detection And Degenerative Disease \\ Control In Elderly In Dsn. Karang Pucang, ds.Ngancar, Kec.Pitu \\ Pitu Health Centre Working Area \\ Ngawi District
}

\author{
Raudhotun Nisak $^{1}$, Siti Maimunah ${ }^{2}$, Tri Admadi ${ }^{3}$ \\ Akademi Keperawatan Pemerintah Kabupaten Ngawi \\ Jl. Dr. Wahidin No 49 Ngawi 63212 Telp. (0351) 744859 \\ email: nisak.arif@gmail.com
}

\begin{abstract}
Abstrak
Penyakit degeneratif merupakan penyakit kronik menahun yang banyak mempengaruhi kualitas hidup serta produktivitas seseorang. Peningkatan beberapa kejadian penyakit ini cenderung meningkat seiring bertambahnya usia sehingga lebih banyak dialami oleh lansia. Upaya pencegahan dan penanganan kejadian tersebut dapat dilakukan dengan tindakan deteksi dini dan sebagai dasar dalam pengendalian kejadian penyakit ini.

Pengabdian masyarakat ini bertujuan untuk mengetahui persentase kejadian hipertensi, gula darah, asam urat dan kolesterol pada lansia. Pengabdian ini dilakukan untuk meningkatkan kesadaran lansia untuk melakukan pemeriksaan secara dini dan berkala, khususnya melalui posyandu lansia.

Pengabdian masyarakat ini terdiri dari 3 kegiatan utama, yaitu jalan sehat, pemeriksaan gula darah, asam urat, dan kolesterol dan pendidikan kesehatan bagi lansia tentang penyakit degeneratif. Hasil: Mayoritas lansia yang terlibat dalam pengabdian masyarakat ini adalah perempuan (72\%). Rerata usia lansia middle age $(59,74 \pm 6,5)$, lansia dengan normotensi sebanyak $57,4 \%$, lansia dengan kadar glukosa normal sebanyak 96,3\%, Kadar asam urat di atas normal sebanyak 90,7\%, dan kadar kolesterol diatas normal sebanyak $61,1 \%$.

Deteksi dini merupakan upaya dasar yang penting dilakukan dalam rangka pengendalian penyakit degeneratif pada lansia. Upaya pengendalian ini dapat dimulai dengan pendidikan kesehatan untuk meningkatkan pengetahuan lansia tentang kejadian penyakit degeneratif.
\end{abstract}

Kata Kunci: lansia, penyakit degeneratif

\section{PENDAHULUAN}

Penyakit degeneratif merupakan penyakit kronik menahun yang banyak mempengaruhi kualitas hidup serta produktivitas seseorang. Penyakit degeneratif antara lain hipertensi, penyakit jantung koroner, kanker, diabetes mellitus, osteoporosis, penyakit sendi, asma, katarak, dan sebagainya. Peningkatan beberapa kejadian penyakit ini cenderung meningkat seiring bertambahnya usia sehingga lebih banyak dialami oleh lansia. Proses pertambahan usia ini juga diiringi dengan terjadinya penurunan fungsi organ tubuh akibat berkurangnya kemampuan sel beregenerasi dan mempertahankan strukturnya (Kholifah, 2016). Hal ini akan sangat mengganggu lansia karena menurunkan kualitas hidup sehingga perlu dilakukan pemeriksaan kesehatan rutin guna memantau munculnya penyakit degeneratif tersebut.

Data dari World Population Prospects dan United Nation (UN) menunjukkan Indonesia merupakan negara dengan persentase penduduk lanjut usia paling tinggi $(37,6 \%)$ dibanding negara ASEAN lainnya. Berdasarkan hasil sensus penduduk Indonesia pada tahun 2010, jumlah populasi lanjut usia di Indonesia berkisar 18,04 juta atau 7,6\% dari total populasi di Indonesia. Angka ini akan terus meningkat mencapai 33,7 juta atau 
$11,8 \%$ pada tahun 2025 dan menjadi 48,2 juta atau $15,8 \%$ pada tahun 2035 . United Nation memprediksikan bahwa persentase penduduk Indonesia berusia di atas 60 tahun akan meningkat menjadi $25 \%$ atau mencapai 74 juta pada tahun 2050(Sri \& Ghazy, 2014). Riset Kesehatan Dasar (Riskesdas) tahun 2013 menyebutkan penyakit terbanyak pada lanjut usia adalah hipertensi $(57,6 \%)$, artritis $(51,9 \%)$, stroke $(46,1 \%)$, masalah gigi dan mulut $(19,1 \%)$, penyakit paru obstruktif menahun $(8,6 \%)$ dan diabetes mellitus $(4,8 \%)$. Sementara itu dengan bertambahnya usia, gangguan fungsional akan meningkat dengan ditunjukkan terjadinya disabilitas. Pada tahun 2014, Riskesdas juga masih menyajikan data yang tidak berbeda dimana penyakit penyakit utama yang dialami para lansia yaitu hipertensi, radang sendi, stroke, PPOK, dan diabetes melitus.

Dusun Karang Pucang Desa Ngancar Kabupaten Ngawi ini memiliki 245 kepala keluarga (KK) dan 159 dari total penduduknya adalah lansia. Berdasarkan data tersebut pula, hanya 25\% lansia yang aktif mengikuti posyandu lansia yang rutin dilaksanakan satu bulan sekali. Keengganan mengikuti kegiatan posyandu lansia ini umumnya disebabkan karena lansia tidak mempunyai keluhan penyakit secara fisik sehingga menganggap diri mereka sehat. Oleh karena itu, upaya peningkatan kesadaran bagi masyarakat, khususnya kelompok lansia perlu dilakukan untuk memberikan pemahaman bahwa melakukan pemeriksaan kesehatan tidak harus menunggu adanya keluhan atau kejadian sakit. namun upaya tersebut perlu dilakukan untuk melakukan pencegahan dan pengendalian terhadap kejadian penyakit degeneratif.

Upaya pencegahan an kejadian tersebut dapat dilakukan dengan tindakan deteksi dini, berupa pemeriksaan yan terkait dengan penyakit degeratif yang rentan dialami oleh lansia. Deteksi secara dini dapat dilakukan dengan pengecekan status gizi, tekanan darah, biokimia darah (khususnya glukosa darah, kolesterol, dan asam urat) secara rutin. Tentunya hasil pada saat deteksi dini dapat digunakan sebagai dasar pencegahan atau pengendalian masalah kesehatan lansia sehingga lansia dapat hidup secara berkualitas.

\section{METODE}

Kegiatan ini merupakan bentuk kegiatan pengabdian kepada masyarakat dengan sasaran 159 lansia di Dusun Karang Pucang, Desa Ngancar Wilayah Puskesmas Pitu. Rangkaian kegiatan ini dilakukan selama 1 bulan di Dusun Karang Pucang, Desa Ngancar Wilayah Puskesmas Pitu Kabupaten Ngawi. Melaui kegiatan ini, diharapkan terjadi peningkatan pemahaman atau pengetahuan bagi lansia tentang deteksi dini dan pengendalian degeneratif serta peningkatan keaktifan dalam kegiatan posyandu lansia.

Pengabdian masyarakat ini terdiri dari 3 kegiatan utama. Kegiatan pertama adalah jalan sehat yang diawali dan diakhiri dengan pengukuran tekanan darah. Kegiatan dilanjutkan dengan pemeriksaan gula darah, asam urat, dan kolesterol. Dia akhir kegiatan, dilakukan kegiatan pendidikan kesehatan bagi lansia tentang penyakit degeneratif.

Instrumen yang digunakan dalam kegiatan pengabdian masyarakat ini adalah alat tulis, alat pengukuran tekanan darah yaitu tensimeter dan stetoskop. Alat lain yang digunakan yaitu alat pengukuran gula darah, asam urat dan kolesterol berupa alat ukur, tissue, lancet, dan pen lancet kapas alkhohol. Sedangkan alat penyuluhan kesehatan berupa sound system, LCD, dan leaflet. Data pengabdian dianalisis secara univariat dan ditampilkan menggunakan tabel dan grafik.

\section{HASIL}

Seluruh peserta yang terlibat kegiatan pengabdian masyarakat ini sebanyak 54 lansia atau 35\% dari target sasaran. Sebagian besar ketidakhadiran ini disebabkan karena di dusun tersebut terdapat salah satu warga yang meninggal dunia sehingga banyak warga bersiap-siap untuk melakukan takziah. Sebagian lansia yang telah datang selanjutnya dilakukan tindakan pemeriksaan tekanan darah sebelum dimulainya kegiatan jalan sehat.

Semua lansia yang datang mengikuti jalan sehat jarak $\pm 50-100$ meter. Pada saat jalan sehat berlangsung, beberapa warga menyatakan senang dengan kegiatan ini karena pada dasarnya lansia jarang sekali melakukan olahraga dalam kesehariannya. Sebagian besar lansia yang mengikuti kegiatan ini adalah perempuan (Grafik 1). 


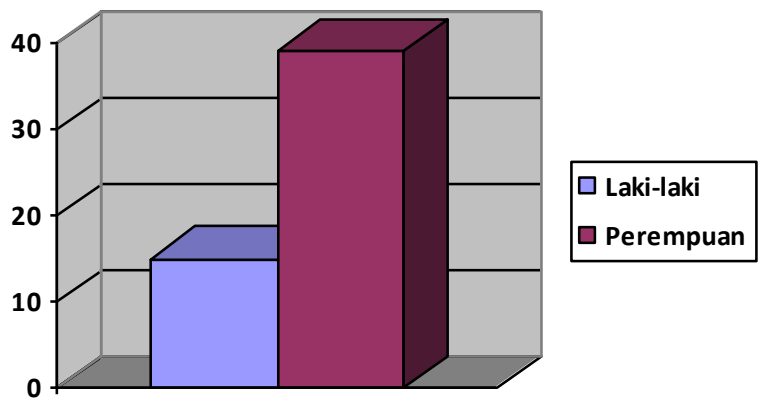

Gambar 1. Karakteristik Sasaran Pengabdian Masyarakat Berdasarkan Jenis Kelamin

Tabel 1. Karakteristik Karakteristik Sasaran Pengabdian Masyarakat Berdasarkan umur, tekanan darah, gula darah, asam urat dan kolesterol

\begin{tabular}{|c|c|}
\hline Karakteristik & Mean \pm SD \\
\hline Umur & $59,74 \pm 6,5$ \\
\hline $\begin{array}{l}\text { Tekanan darah sistol } \\
\text { sebelum jalan sehat }\end{array}$ & $129(100-170)$ \\
\hline $\begin{array}{l}\text { Tekanan darah diastol } \\
\text { sebelum jalan sehat }\end{array}$ & $80(60-110)^{*}$ \\
\hline $\begin{array}{l}\text { Tekanan darah sistol } \\
\text { setelah jalan sehat }\end{array}$ & $134(110-170)^{*}$ \\
\hline $\begin{array}{l}\text { Tekanan darah diastol } \\
\text { setelah jalan sehat }\end{array}$ & $82(70-110)^{*}$ \\
\hline Kadar asam urat & $4,2 \pm 2,39$ \\
\hline Kadar gula darah & $121 \pm 37,07$ \\
\hline Kadar kolesterol & $173 \pm 43,8$ \\
\hline
\end{tabular}

*(Minimum-Maksimum)

Sebagian besar lansia yang terlibat dalam pengabdian masyarakat ini memiliki tekanan darah dan gula darah normal (tabel 2 dan tabel 3), namun memiliki kadar asam urat dan kolesterol di atas normal (tabel 4 dan tabel 5).

Berikut adalah rincian masingmasing hasil pemeriksaan:

Tabel 2. Karakteristik Karakteristik Sasaran Pengabdian Masyarakat Berdasarkan Tekanan Darah

\begin{tabular}{lcc}
\hline \multicolumn{1}{c}{ Karakteristik } & n & \% \\
\hline Normal & 31 & 57,4 \\
Hipertensi ringan & 16 & 29,6 \\
Hipertensi sedang & 7 & 13 \\
\hline Total & 54 & 100
\end{tabular}

Tabel 3. Karakteristik Sasaran Pengabdian Masyarakat Berdasarkan Gula Darah

\begin{tabular}{|c|c|c|}
\hline Karakteristik & $\mathbf{n}$ & $\%$ \\
\hline Normal & 52 & 96,3 \\
\hline Hiperglikemia & 4 & 3,7 \\
\hline Total & 54 & 100 \\
\hline \multicolumn{3}{|c|}{$\begin{array}{l}\text { Tabel 4. Karakteristik Karakteristik Sasaran } \\
\text { Pengabdian Masyarakat Berdasarkan Kadar } \\
\text { Asam Urat }\end{array}$} \\
\hline Karakteristik & $\mathbf{n}$ & $\%$ \\
\hline Normal & 5 & 9,3 \\
\hline Di atas normal & 49 & 90,7 \\
\hline Total & 54 & 100 \\
\hline
\end{tabular}

Tabel 5. Karakteristik Karakteristik Sasaran Pengabdian Masyarakat Berdasarkan Kadar Kolesterol

\begin{tabular}{lcc}
\hline \multicolumn{1}{c}{ Karakteristik } & n & \% \\
\hline Normal & 21 & 38,9 \\
Di atas normal & 24 & 61,1 \\
\hline Total & 54 & 100 \\
\hline
\end{tabular}

\section{PEMBAHASAN}

Sebagian besar lansia yang mengikuti kegiatan pengabdian masyarakat ini adalah perempuan $(72 \%)$. Hal ini sebagaimana yang dirilis oleh Pusat Data dan Informasi Kemenkes RI bahwa penduduk Indonesia pada tahun bahwa prosentase penduduk lansia tahun 2017 lebih banyak perempuan dibandingkan laki-laki. Disampaikan pula, bahwa porsentase ini juga menunjukkan bahwa angka harapan hidup lansia perempuan di Indonesia lebih tinggi dibandingkan lansia laki-laki.

Usia lansia yang terlibat dalam kegiatan pengabdian masyarakat ini memperlihatkan bahwa rata-rata lansia berumur 59 tahun. Jika dilihat berdasarkan kategori WHO, maka lansia tersebut berada dalam kategori lansia middle age (45-59 tahun). sedangkan menurut Depkes RI (2009), usia 59 tahun berada dalam kategori lansia akhir.

Hasil pemeriksaan tekanan darah pada kegiatan pengabdian masyarakat ini juga menunjukkan bahwa sebagian besar lansia berada dalam kategori tekanan darah normal $(57,4 \%)$. Secara umum, hal ini tidak sejalan dengan hasil penelitian Budi dkk 
(2011) bahwa semakin bertambah usia, semakin tinggi pula kejadian hipertensi. Hal ini terjadi karena pada usia tersebut arteri besar kehilangan kelenturannya dan menjadi kaku karena itu darah pada setiap denyut jantung dipaksa untuk melalui pembuluh darah yang sempit daripada biasanya dan menyebabkan naiknya tekanan darah. Namun demikian, hasil penelitian Noviningtyas (2014) menjelaskan bahwa kemungkinan sedikitnya kejadian hipertensi pada lansia disebabkan karena asupan nutrisi, khususnya makanan dengan kandungan kalium dan magnesium tinggi. Kadar kalium yang tinggi dapat meningkatkan ekskresi natrium, sehingga dapat menurunkan volume darah dan tekanan darah. Sedangkan magnesium dapat membantu otot jantung untuk relaksasi sehingga dapat menurunkan resiko terjadinya hipertensi (Andarini, 2012).

Hasil pemeriksaan gula darah juga menunjukkan bahwa sebagian besar lansia memiliki gula darah yang normal $(96,3 \%)$. Namun demikian, hasil pemeriksaan gula darah ini tidak sejalan dengan hasil pemeriksaan asam urat dan kolesterol. Dimana hasil pemeriksaan menunjukkan bahwa sebagian besar lansi mengalami kenaikan pada kadar asam urat $(90,7 \%)$ dan kolesterol $(61,1 \%)$. Perbedaan pada hasil ini dimungkinkan karena lansia tidak cukup menerapkan asupan makan yang tepat, khususnya pada makanan yang dapat meningkatkan asam urat dan kolesterol. Sehingga adanya nilai yang sebagian besar normal hanya terjadi pada gula darah. Asupan gizi yang tepat sangat diperlukan bagi lansia agar dapat mempertahankan kualitas hidupnya, dengan mengurangi makanan yang dapat mengurangi kualitas kesehatan (Fitriani, 2012).

Hasil pengabdian masyarakat yang telah dilkukan ini juga menggambarkan bahwa pada dasarnya lansia rentan dengan sakit. Hal ini sejalan dengan RISKESDAS (2013), dimana angka kejadian sakit meningkat seiring bertambahnya usia. Adapun masalah kesehatan yang sering terjadi pada lansia adalah hipertensi artritis, stroke, masalah gigi dan mulut, penyakit paru obstruktif menahun, dan diabetes mellitus.

Oleh karena itu, sebagai hasil deteksi dini ini merupakan dasar yang tepat untuk dilakukannya penyuluhan. Adanya peningkatan pengetahuan tentang kejadian penyakit degeneratif dan solusinya langkah awal yang tepat sebagai dasar pencegahan maupun penanganan masalah kesehatan lansia sehingga lansia dapat hidup secara berkualitas.

\section{SIMPULAN DAN SARAN}

Deteksi dini merupakan upaya dasar yang penting dilakukan dalam rangka pengendalian penyakit degeneratif pada lansia. Upaya pengendalian ini dapat dimulai dengan pendidikan kesehatan untuk meningkatkan pengetahuan lansia tentang kejadian penyakit degeneratif. Adanya evaluasi lebih lanjut atas penerapan pendidikan kesehatan yang telah diberikan pada lansi yang terlibat dalam pengabdian masyarakat ini khususnya, dan masyarakat pada umumnya.

\section{UCAPAN TERIMAKASIH}

Ucapan terimakasih disampaikan kepada Kepala Desa Ngancar, kepala dusun Dusun Karang Pucang, ibu-ibu kader dan warga Desa Ngancar Wilayah Puskesmas Pitu yang telah membantu kegiatan terlaksananya program pengabdian masyarakat.

\section{DAFTAR PUSTAKA}

Badan Penelitian dan Pengembangan Kesehatan Kementerian Kesehatan RI. 2013. Riset Kesehatan Dasar RISKESDAS 2013. Jakarta: Badan Penelitian dan Pengembangan Kesehatan Kementerian Kesehatan RI

Badan Penelitian dan Pengembangan Kesehatan Kementerian Kesehatan RI. 2014. Riset Kesehatan Dasar RISKESDAS 2014. Jakarta: Badan Penelitian dan Pengembangan Kesehatan Kementerian Kesehatan RI

Fitriani, Erda. 2012. Pola Kebiasaan Makan Orang Lanjut Usia (Studi Kasus: Penderita Penyakit Hipertensi Sukubangsa Minangkabau di Jakarta). Humanus Vol XI No 2 diakses pada https://media.neliti.com/media/publicati ons/7114-ID-pola-kebiasaan-makan- 
orang-lanjut-usia-studi-kasus-penderitapenyakit-hipertensi.pdf pada Rabu 28 Maret 2018

Kholifah, S. N .(2016). Keperawatan Gerontik. Jakarta: Kementerian Kesehatan Republik Indonesia : Pusat Pendidikan Sumber Daya Manusia Kesehatan Badan Pengembangan dan Pemberdayaan Sumber Daya Manusia Kesehatan.

Novitaningtyas, Tri. 2014. Hubungan Karakteristik (Umur, Jenis Kelamin, Tingkat pendidikan dan Aktivitas Fisik) dengan Tekana Darah pada Lansia di Kelurahan MakamHaji Kecamatan Kartasura Kabupaten Sukoharjo. Naskah Publikasi di akses pada http://eprints.ums.ac.id/29084/9/02._Nas kah_Publikasi.pdf pada Rabu 28 Maret 2018

Puspaningtyas, DE, Putriningtyas, ND. (2017). Deteksi Masalah Kesehatan Bagi Lanjut Usia Kelurahan Pakunten Kecamatan Wirobrajan. Ilmu Gizi Indonesia, Vo 01 No 01 diakses pada ilgi.respati.ac.id/index.php/ilgi2017/artic le/download/15/9 pada Rabu 28 Maret 2018

Sri MA dan Ghazy M. Horst P (UNFPA), editor. 2014. UNFPA Indonesia Monograph Series: No.1, Indonesia on the Threshold of Population Ageing. Jakarta: United Nations Population Fund [UNFPA] Indonesia

Budi, Ls., Sulchan, HM., Wardani, RS. 2011. Beberapa Faktor yang Berhubungan dengan Tekanan Darah pada Usia Lanjut di RW VIII Kelurahan Krobokan Kecamatan Semarang Barat Kota Semarang. Abstrak. Fakultas Kesehatan Masyarakat Universitas Muhammadiyah Semarang.

Andarini. 2012. Terapi Nutrisi Pasien Usia Lanjut yang Dirawat di RS. Dalam : Harjodisastro D, Syam AF, Sukrisman L, editor. Dukungan nutrisi pada kasus penyakit dalam. Jakarta : Departemen ilmu penyakit dalam Fakultas Kedokteran UI.
Pusat Data dan Informasi Kementrian Kesehatan RI. 2017. Data dan Informasi (Profil Kesehatan Indonesia 2016). Jakarta: Pusat Data dan Informasi Kementrian Kesehatan RI 